\title{
Video Article \\ Extraction of High Molecular Weight DNA from Microbial Mats
}

\author{
Benjamin S. Bey, Erin B. Fichot, R. Sean Norman
}

Department of Environmental Health Sciences, Arnold School of Public Health, University of South Carolina

Correspondence to: R. Sean Norman at rsnorman@mailbox.sc.edu

URL: http://www.jove.com/video/2887/

DOI: $10.3791 / 2887$

Keywords: Molecular Biology, Issue 53, Metagenomics, extracellular polymeric substances, DNA extraction, Microbial mats, hypersaline, extreme environment,

Date Published: $7 / 7 / 2011$

Citation: Bey, B.S., Fichot, E.B., Norman, R.S. Extraction of High Molecular Weight DNA from Microbial Mats. J. Vis. Exp. (53), e2887, DOI : $10.3791 / 2887(2011)$.

Abstract

Successful and accurate analysis and interpretation of metagenomic data is dependent upon the efficient extraction of high-quality, high molecular weight (HMW) community DNA. However, environmental mat samples often pose difficulties to obtaining large concentrations of high-quality, HMW DNA. Hypersaline microbial mats contain high amounts of extracellular polymeric substances (EPS)1 and salts that may inhibit downstream applications of extracted DNA. Direct and harsh methods are often used in DNA extraction from refractory samples. These methods are typically used because the EPS in mats, an adhesive matrix, binds DNA ${ }^{2,3}$ during direct lysis. As a result of harsher extraction methods, DNA becomes fragmented into small sizes ${ }^{4,5,6}$.

The DNA thus becomes inappropriate for large-insert vector cloning. In order to circumvent these limitations, we report an improved methodology to extract HMW DNA of good quality and quantity from hypersaline microbial mats. We employed an indirect method involving the separation of microbial cells from the background mat matrix through blending and differential centrifugation. A combination of mechanical and chemical procedures was used to extract and purify DNA from the extracted microbial cells. Our protocol yields approximately $2 \mu \mathrm{g}$ of HMW DNA (35-50 $\mathrm{kb})$ per gram of mat sample, with an $\mathrm{A}_{260 / 280}$ ratio of 1.6. Furthermore, amplification of $16 \mathrm{~S}$ rRNA genes ${ }^{7}$ suggests that the protocol is able to minimize or eliminate any inhibitory effects of contaminants. Our results provide an appropriate methodology for the extraction of HMW DNA from microbial mats for functional metagenomic studies and may be applicable to other environmental samples from which DNA extraction is challenging.

\section{Video Link}

The video component of this article can be found at http://www.jove.com/video/2887/

Protocol

\section{Microbial Cell Extraction:}

1. Homogenize microbial mats with a sterile grinding pestle by mixing thoroughly. Place approximately all $30 \mathrm{~g}$ (wet weight) of homogenized mat material into sterile container of Waring blender, add about $100 \mathrm{~mL}$ of $1 \mathrm{M} \mathrm{NaCl}$ (or a concentration specific to sample in use), and blend three times at medium speed for $1 \mathrm{~min}$ with intermittent cooling in a $-20^{\circ} \mathrm{C}$ freezer for $1 \mathrm{~min}$. Transfer the slurry into a $250 \mathrm{~mL}$ centrifuge bottle and fill the remaining empty volume with $1 \mathrm{M} \mathrm{NaCl}$. Prepare $\mathrm{NaCl}$ solution in autoclaved DI water and filter sterilize it.

2. Further dislodge the microbial cells from the matrix by shaking $(150 \mathrm{rpm})$ using a vortexer (Vortex-Genie $\left.{ }^{\mathrm{R}} 2\right)$ at room temperature for $30 \mathrm{~min}$.

3. Centrifuge at low speed $(500 \mathrm{x} \mathrm{g})$ for $15 \mathrm{~min}$ at $4^{\circ} \mathrm{C}$. Gently transfer the supernatant into a flask with minimum disturbance to the sediment.

4. Using the pelleted sediment, repeat blending and steps 1.2 and 1.3 four additional times with the addition of fresh $\mathrm{NaCl}$ to each sediment pellet at the end of step 1.3. The supernatant from each $\mathrm{NaCl}$ extraction is transferred into a fresh flask.

5. Combine the supernatants from the 5 cell extractions and centrifuge in aliquots of $200 \mathrm{~mL}$ at high speed $(25,000 \times \mathrm{g})$ for $15 \mathrm{~min}$ at $4{ }^{\circ} \mathrm{C}$. Discard the supernatant, resuspend each cell pellet in $10 \mathrm{~mL}$ of $2 \%$ sodium hexametaphosphate, combine pellets and make up the volume to $200 \mathrm{~mL}$ with $2 \%$ sodium hexametaphosphate. Wash cells by shaking (150 rpm) at room temperature for $30 \mathrm{~min}$. At the end of this step you should have only one tube of cells to proceed to the next step.

6. Centrifuge at high speed $(25,000 \mathrm{x} \mathrm{g})$ for $15 \mathrm{~min}$ at $4^{\circ} \mathrm{C}$. Discard the supernatant, resuspend cell pellet in $200 \mathrm{~mL}$ of TE (50 mM EDTA), and wash cells by shaking $(150 \mathrm{rpm})$ at room temperature for $10 \mathrm{~min}$.

7. Centrifuge at high speed $(25,000 \times \mathrm{g})$ for $15 \mathrm{~min}$ at $4^{\circ} \mathrm{C}$, discard the supernatant, resuspend in $15 \mathrm{~mL}$ TE $(10 \mathrm{mM}$ EDTA), and store $200-\mu \mathrm{L}$ aliquots at $-80^{\circ} \mathrm{C}$ until needed for DNA extractions.

\section{DNA Extraction and Purification:}

1. Add $200 \mu \mathrm{L} 5 \mathrm{M} \mathrm{NaCl}, 200 \mu \mathrm{L} 10 \%$ SDS, and $100 \mu \mathrm{L} 14.3 \mathrm{M} \beta$-mercaptoethanol to the $200-\mu \mathrm{L}$ microbial cell aliquot. Mix gently by inverting 4-6 times.

2. Subject the mixture to 3 rounds of freeze-thaw by submerging in liquid nitrogen for 2 min followed by thawing in a $65^{\circ} \mathrm{C}$ water bath for 5 min. Extend final thawing to $10 \mathrm{~min}$.

3. Add $200 \mu \mathrm{L} 5 \mathrm{M}$ potassium acetate $\left(\mathrm{pH} \mathrm{5.5)}\right.$ and place on ice for $10 \mathrm{~min}$. Centrifuge at $10,000 \mathrm{xg}$ for $10 \mathrm{~min}$ at $4^{\circ} \mathrm{C}$ and transfer the supernatant to a new tube using a wide-bore pipette tip. Add $3 \mu \mathrm{L}$ of RNase $\mathrm{A}$ and incubate $a 7^{\circ} \mathrm{C}$ for $1 \mathrm{hr}$. 
4. Add equal volume of chloroform, shake briefly by inversion, and centrifuge at $15,000 \times \mathrm{g}$ for $10 \mathrm{~min}$ at room temperature.

5. Carefully transfer the top layer of supernatant into a new tube using a wide-bore pipette tip. Avoid pipetting the white interface layer located between the top and bottom layers. Repeat the chloroform-extraction procedure.

6. Add an equal volume of chilled $\left(\right.$ at $\left.-20^{\circ} \mathrm{C}\right)$ isopropanol to the supernatant and incubate on ice for 30 min to precipitate DNA.

7. Centrifuge at max speed $(20,800 \times \mathrm{g})$ for $10 \mathrm{~min}$ at $4^{\circ} \mathrm{C}$ to pellet DNA.

8. Discard the supernatant and wash DNA pellet with $1 \mathrm{~mL}$ of chilled $\left(\right.$ at $\left.-20^{\circ} \mathrm{C}\right) 70 \%$ ethanol.

9. Centrifuge at max speed $(20,800 \times \mathrm{g})$ for $10 \mathrm{~min}$ at $4^{\circ} \mathrm{C}$, discard the supernatant, repeat $70 \%$ ethanol wash, and air-dry DNA pellet for 10 min. Repeat $70 \%$ ethanol wash.

10. Resuspend DNA in $25 \mu \mathrm{L}$ TE (10 mM EDTA), warm at $65^{\circ} \mathrm{C}$ for $5 \mathrm{~min}$, combine into one tube if multiple tubes have been used, and make-up volume to $500 \mu \mathrm{L}$ with TE.

11. Add $500 \mu \mathrm{L}$ ice-cold (or at $4^{\circ} \mathrm{C}$ ) $20 \%$ polyethylene glycol (PEG) (prepared in $1.2 \mathrm{M} \mathrm{NaCl}$ ). Mix gently by inversion, incubate on ice for 10 min, and centrifuge at maximum speed for $10 \mathrm{~min}$ at $4^{\circ} \mathrm{C}$ to pellet DNA. Remove and discard the supernatant and wash the pelleted DNA with 1 $\mathrm{mL}$ of chilled $70 \%$ ethanol, air-dry for $10 \mathrm{~min}$, and resuspend in 30-50 $\mu \mathrm{L}$ TE or molecular grade water. Facilitate resuspension of DNA by warming at $65^{\circ} \mathrm{C}$ for 5 min and Store DNA at $-80^{\circ} \mathrm{C}$.

\section{DNA Purity, Concentration and Size Determination:}

1. Determine DNA quality by measuring the $A_{260 / 280}$ and $A_{260 / 230}$ ratios using a Nanodrop 1000 spectrophotometer or any other appropriate instrumentation.

2. Determine DNA concentration using Quant-iT dsDNA Assay kit according to the manufacturer's instructions.

3. Determine DNA size using pulse field gel electrophoresis. Prepare $1 \%$ agarose gel with $0.5 X$ TBE and use the following parameters on the CHEF Mapper XA System; initial switch time of $0.35 \mathrm{~s}$, a final switch time of $7.67 \mathrm{~s}$, and $120^{\circ}$ included angle for a gradient of $6.0 \mathrm{~V} / \mathrm{cm}$ at a linear ramping factor. Stain gel with 1 x SYBR Green I for $30 \mathrm{~min}$. Load between 700-1000 ng total DNA on gel. See Fig. 3 for a condensed form of the complete protocol.

\section{Representative Results:}

\section{Cell extraction:}

Sequential microbial cell extracts (supernatants) have shown that the turbidity of extracts decreases as the number of extractions increase. This suggests a reduction in the number of cells following each successive cell extraction. Important to note here is that as each additional cell extraction step provides the opportunity for contaminant introduction, the number of cell extractions should be minimized so that the final cell pellet is representative of the overall microbial community. Other sources of contamination were controlled by adopting adequate laboratory sterile techniques. For instance, the solutions were prepared in autoclaved DI water and filter sterilized. Containers were sterilized with alcohol, autoclaved, and treated under UV light and ultraviolet crosslinker.

\section{DNA concentration and quality determination:}

The protocol yielded approximately $2 \mu \mathrm{g}$ of HMW DNA (35-50 kb) (Fig. 4) per gram of mat sample with an $A_{260 / 280}$ ratio of 1.6, and an $A_{260 / 230}$ ratio of 0.7 (Table 1). Although the $A_{260 / 230}$ ratio appeared to be low, no inhibition of downstream molecular-based application such as PCR-amplification of the $16 \mathrm{~S}$ rRNA genes was observed in a separate study ${ }^{7}$. It is important to note that DNA from hypersaline mats has two main sources of contamination; EPS and salts. It is therefore possible that traces of these contaminants may be influencing the $A_{260 / 230}$ ratios despite the tremendous efforts to reduce their effects on down stream applications.

\section{DNA size determination:}

Pulse field gel electrophoresis employs a pulsating current flow with intermittent directional switches resulting in a DNA smear as shown in figure 3. Our protocol yielded a HMW DNA of approximately $35-50 \mathrm{~kb}$. While some DNA size may be smaller than $30 \mathrm{~kb}$, it is important to have part of the smear above $35 \mathrm{~kb}$ given that fosmid cloning requires $40 \mathrm{~kb}$ DNA inserts and larger DNA fragments provide greater access to intact biosynthetic pathways. In our studies, the DNA smear above $35 \mathrm{~kb}$ was excised and purified for large-insert vector cloning and other molecular applications. 


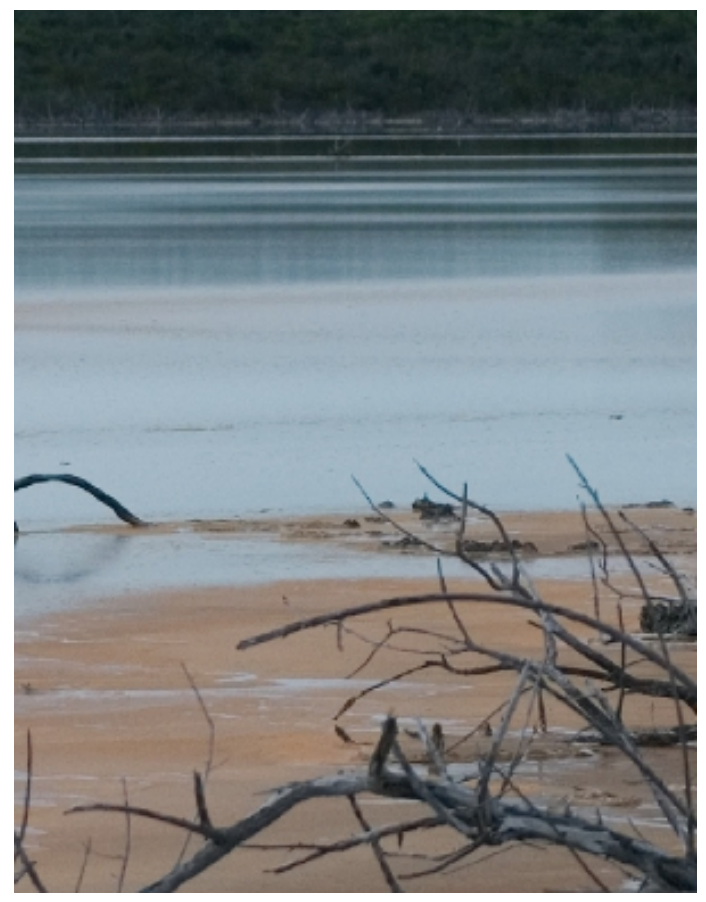

Figure 1. Hypersaline microbial mat sampling site (Big Pond) located on Eleuthera, The Bahamas.

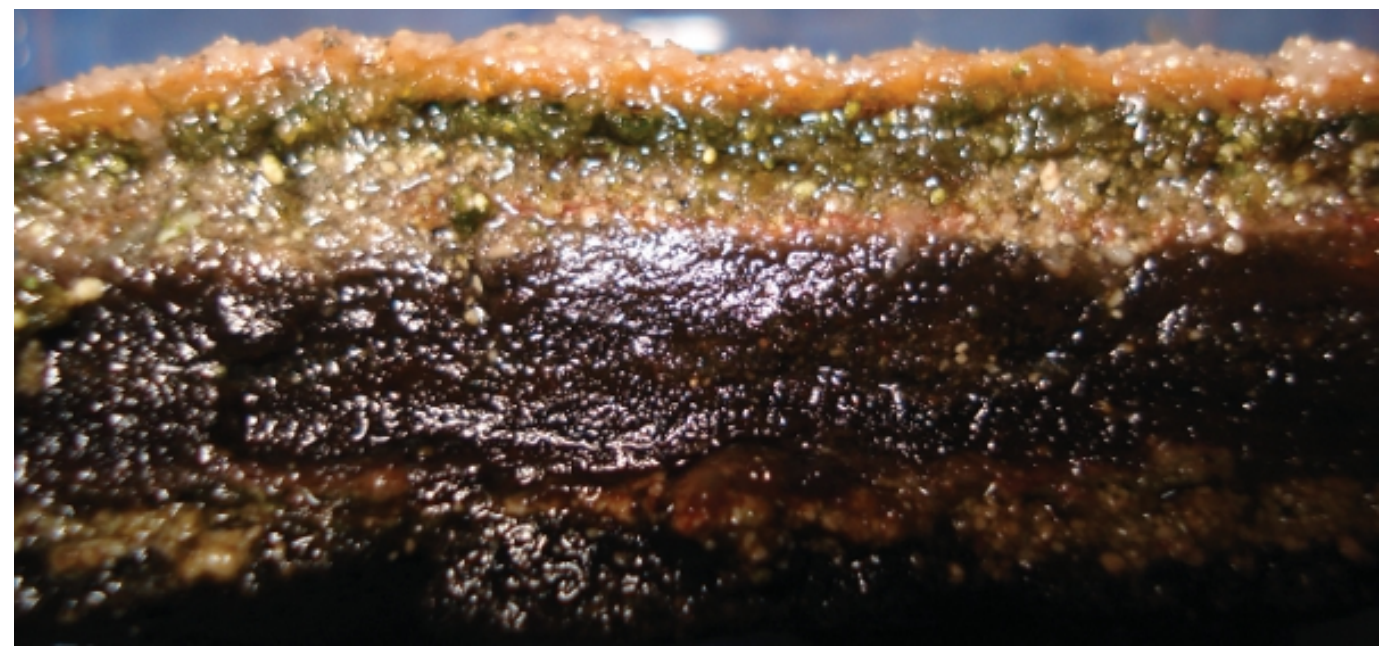

Figure 2. A cross-section of the hypersaline microbial mat used in this study. The microbial mat was obtained from a hypersaline pond located on Eleuthera, The Bahamas.

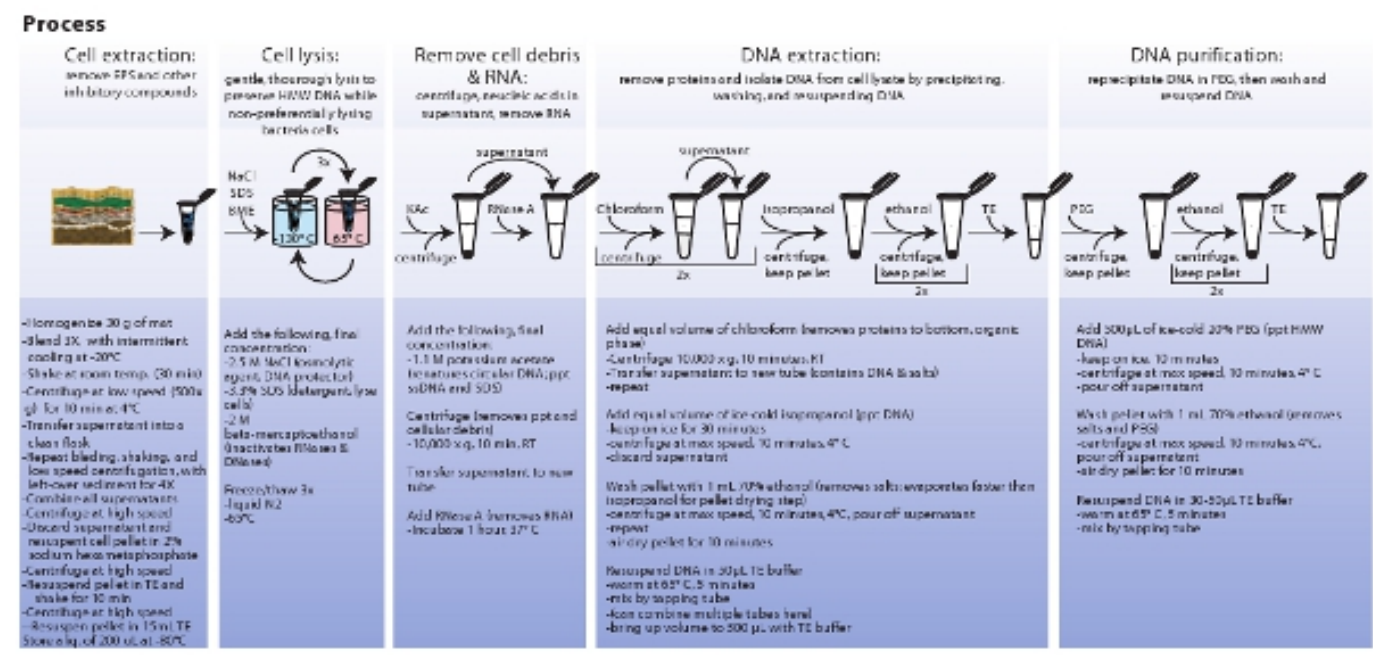

Figure 3. Schematic representation of procedures involved in microbial cell extraction, cell lysis, extraction, and purification of metagenomic DNA. Click here to view a larger image. 


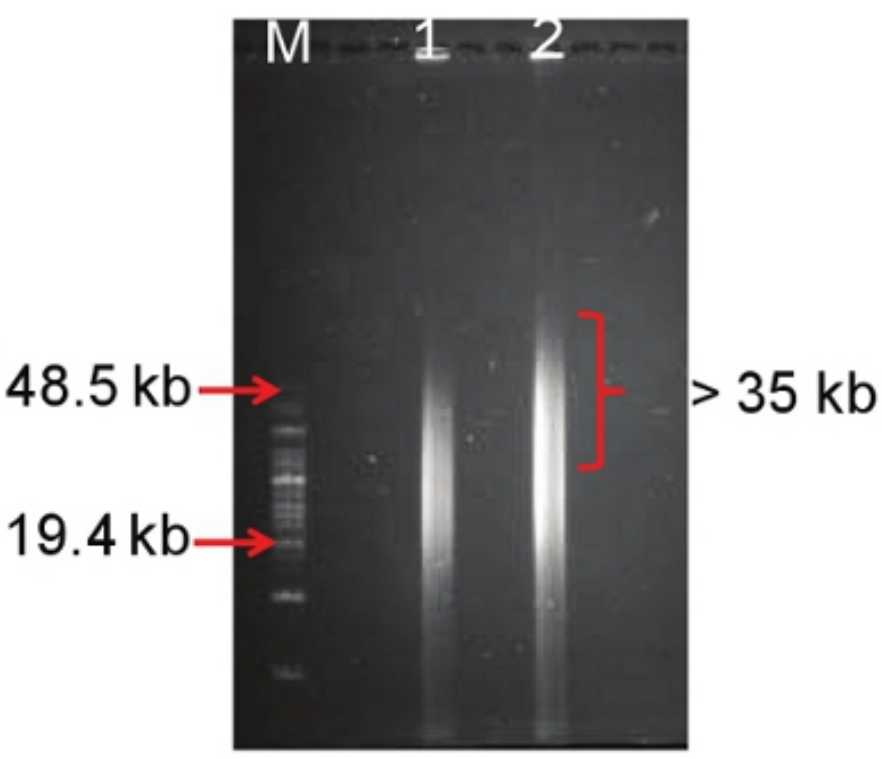

Figure 4. Molecular weight characterization of extracted DNA using pulse field gel electrophoresis. Lane M is a HMW marker, and lanes 1 and 2 are replicates of metagenomic DNA extracted from the Eleuthera hypersaline mat using the above protocol.

\begin{tabular}{|lllll|}
\hline Extraction Method & & Concentration $\mathbf{~ g / g}$ & $\mathbf{A}_{\mathbf{2 6 0 / 2 8 0}}$ & \multicolumn{1}{c|}{$\mathbf{A}_{\mathbf{2 6 0} 2 \mathbf{2 3 0}}$} \\
PEG & Rep 1 & 1806.1 & 1.64 & 0.76 \\
& Rep 2 & 2010.8 & 1.61 & 0.75 \\
\hline
\end{tabular}

Table 1. Measurement of concentration and quality of DNA extracted from microbial hypersaline mat.

\section{Discussion}

Given that total cell removal from complex and highly diverse microbial mat samples is not practical, the primary concern is how well the extracted cells represent the overall microbial mat community. In a previous study, PCR-DGGE analysis of microbial 16S rRNA genes showed that the five cell removal steps used in this protocol extracts cells that are representative of the overall microbial mat community ${ }^{7}$. The actual number of cell extraction steps required to provide a cell pellet that is representative of the overall microbial community will likely change dependent upon sample type. For optimal protocol development for different samples, a small-scale pilot study is recommended wherein empirical testing of the microbial richness recovered after each cell extraction step is compared to the richness of the original community.

Fosmid cloning requires HWM DNA of 35-40 kb for clone library construction ${ }^{8}$. Our protocol yielded DNA with sizes ranging from 35-50 kb (Fig. 4) and was successfully used to generate a fosmid-based metagenomic library (unpublished results). Other protocols used in DNA extraction from EPS-producing marine bacteria yielded $\sim 23 \mathrm{~kb}^{4}$. In functional metagenomic studies, large DNA fragments provide greater access to a wide range of genes encoding for biosynthetic pathways as well as for functional behaviors 9,10 . Thus, HMW DNA is an important requirement for metagenomic studies. Generating large-insert metagenomic libraries from environmental samples will increase the chances of discovering novel biosynthetic pathways that may lead to the discovery of novel genes. This protocol may be used to extract DNA from other refractory environmental samples.

\section{Disclosures}

No conflicts of interest declared.

\section{Acknowledgements}

This work was funded by the National Science Foundation Environmental Genomics Program (Grant No. EF-0723707).

\section{References}

1. Decho, A.W. Microbial biofilms in intertidal systems: an overview. Cont. Shelf Res. 20, 1257-1273 (2000).

2. Dupraz, C., \& Visscher, P.T. Microbial lithification in marine stromatolites and hypersaline mats. Trends Microbiol. 13, 429-438 (2005).

3. Steffan, R.J., Goksoyr, J., Boj, A.K., \& Atlas, R.M. Recovery of DNA from soils and sediments. Appl. Environ. Microbiol. 54, 2908-2915 (1988).

4. Lee, Y.K., Kim, H.W., Liu, C.L., \& Lee, H.K. A simple method for DNA extraction from marine bacteria that produce extracellular materials. J. Microbiol. Methods. 52, 245-250 (2003).

5. Roose-Amsaleg, C.L., Garnier-Sillam, E., \& Harry, M. Extraction and Purification of Microbial DNA from Soil and Sediment Samples. Appl. Soil Ecol. 18, 47-60 (2001).

6. de Lipthay J.R., Enzinger C., Johnsen K., Aamand J., \& Sørensen, S.J. Impact of DNA extraction method on bacterial community composition measured by denaturing gradient gel electrophoresis. Soil Biol. Biochem. 36, 1607-1614 (2004).

7. Bey, B.S., Fichot, E.B., Dayama, G., Decho, A.W., \& Norman, R.S. Extraction of High Molecular Weight DNA from Microbial Mats. Biotechniques. 49, 631-640 (2010). 
8. Kakirde, S.K., Parsley, L.C., \& Liles, M.R. Size does matter: Application-driven approaches for soil metagenomics. Soil Biology \& Biochemistry. 42, 1911-1923 (2010).

9. Rodon, M.R., August, P.R., Bettermann, A.D., Brady, S.F., Grossman, T.H., Liles, M.R., Loiacono, K.A., Lynch, B.A., MacNeil, I.A., Minor, C., Tiong, C.L., Gilman, M., Osburne, M.S., Clardy, J., Handelsman, J., \& Goodman, R.M. Cloning the Soil Metagenomic: A Strategy for Accessing the Genetic and Functional Diversity of Uncultured Microorganisms. Appl. Environ. Microbiol. 66, 2541-2547 (2000).

10. Beja, O., Aravind, L., Koonin, E.V., Suzuki, M.T., Hadd, A., Nguyen, L.P., Jovanovich, S.B., Gates, C.M., Feldman, R.A., Spudich, J.L., Spudich, E.N., \& DeLong, E.F. Bacterial Rhodopsin: Evidence for a New Type of Phototrophy in the Sea. Science. 289, 1902-1906 (2000). 